\title{
Education Personification Theory on the Historicity of Classical Greek Philosophers
}

\author{
Charles Ogundu Nnaji \\ Department of Philosophy and Religions, Faculty of Arts, University of Abuja, Abuja, Nigeria \\ Email: economos34@yahoo.com
}

Received 15 September 2015; accepted 18 March 2016; published 21 March 2016

Copyright (C) 2016 by author and Scientific Research Publishing Inc.

This work is licensed under the Creative Commons Attribution International License (CC BY). http://creativecommons.org/licenses/by/4.0/

(c) (i) Open Access

\section{Abstract}

The study in its scope questions the historical existence of ancient Greek philosophers; while it focuses on two educational relevance themes a) that there is strength in recent insinuations that classical (ancient) Greek philosophers are only but true to reality, existing in nothing but personified names bearing their philosophical (teachings) in the meanings of their names; e.g. Heraclitus, simply is fire, Socrates is sorcery, then Pythagoras is puthon, i.e. fortune teller, since his history is replete with occult learning in Egypt and the Chaldea; b) our classist method of research leading to our research conclusions and findings touches on the second angle to this essay, which is a frank educational demand for the original Greek documents of these Greek classical philosophers, since it is suspected that these documents (e.g. Dialogues and Phaedo of Plato etc.) never existed or that translations to English had been manipulated, hence the truth was yet to be told about the true origins and the true meaning of philosophy. Particularly, if philosophy is merely love for wisdom, how come the Bible totally condemned it (Colossians 2:8, 2 Peter 1:16). Then how come Emperor Justinian banned it in 529 CE. (New \& Philips, 1953, Brockman and Pescantini, 2004, philosophy NET, 2015). Justinian banned philosophy, since medieval Christian heretical teachings were products of Christian philosophical arguments which almost destroyed Christianity in it earliest stages (i.e. 1300 CE - 526 CE) Boer, 1980: pp. 41-60.

\section{Keywords}

Education-Personification-Theory, Historicity, Classical, Greek, Philosopher

\section{Study Bywords}

The earliest use of the word philosophy includes

1) Genesis 3: 15 Ophensuphek (the serpent attacks; Mathew 10:16).

2) Genesis 11: 7-9, "Phalasaph” (Balasapha) Philisapha, confused speech. 
3) Isaiah 2:6, Ezekiel 13:18-20, "Pilosophiku” (KJV) or Philosophiku (i.e. consulting magic and witchcraft) Isaiah 8:9 being what Socrates were executed for in 399CE.

\section{Research Synthesia}

In a nutshell, that philosophy is clearly invented (2 Peter 1:16 "sesophis") myth or educational field of study with ancient thinkers who never existed, but personified to suit its purpose on the basis of the Greek "Edoken" (i.e. what I have, I give you) Metzger, 2001.

\section{Laid Down Proto (First) Hypothesis for This Study}

This study puts forward for debate this question, "Did ancient Greek philosophers actually exist?” There are reliable evidence laid or put forward recently by historians to identify factual historical personalities. Simply put virtually out of every ten names of ancient philosophers, nine of such names means exactly those philosophers assertions "Are these mere coincidences or otherwise?" For example, Heraclitus means fire; Parmenides is permanence, Socrates is sorcery; Pythagoras was being fortune teller (Greek "Puthon", Hebrew "Sophis", i.e. serpent spirit of fortune telling) Aland \& Newman, 1983: p. 157. Pythagoras is being among the first to inquire or foretell through the pythia occult-Orpheas of Dionysus. Anaxagoras, Anaximander and Anaximenes, all means deep in the past, i.e. ancient thoughts on the existence of God or gods (Ana; in the past) menes (meni= god; or the gods who counts your number of years (Hebrew "Sapher or Sopher" is learned enough to count) BDB, 2007, pp 704-708, while Plato has much with the Hebrew "Philaot" (i.e. Nephes or Nephili) or the soul, or the extraordinary. Aristotle is what the name suggests; i.e. Areo (Hill, height, perfectionist or a master) i.e. someone with a great mind or thinking ability (Hebrew “Aron” i.e. crafty or cunning) Hebrew Old Testament, 2005.

\section{Problems of Historical Methods in the Historicity of Ancient Greek Philosophers}

1) What are the sources of history; which in the study of history is called "Historiography" i.e. in writing the history of philosophy particularly ancient Greek philosophy, what were the sources of the documents?

2) Are the real or original ancient Greek language documents of ancient philosophers still available; i.e. can a researcher still obtain philosophy as written by Plato in their original Greek not merely the Latin, German, French and English translations.

3) What role did oral tradition play in reconstructing the history of ancient Greek philosophy (Maer, 1988).

4) Is it not reliably possible that these ancient classical (i.e. best of ancient) Greek philosophers existed only in names, personified as human characters (Chambers, 1996) p. 1033.

\section{Proofs for "d" Above}

(i.e. Names ancient philosophers they bear actually are coded meanings of their philosophical positions).

1) Socrates is socsratim (i.e. sorcery is magic). He was a member of the python or pythia serpent cult of Delphi (Plato’s Dialogues cited by Asaju, 1999: p. 36). Hence he was sentenced to death in 399BC in Athens.

2) Socrates mothers name was "Sophron" which means a wise woman (Aland \& Newman, 1983). Socrates NET, 2011.

\section{Deutero or Supporting Hypothesis for This Study}

1) That philosophy is a cleverly crafted, invented, devised or cunningly made up "muthos" or sophis: (2 Peter 1:16, Brown \& Comfort, 1990 Interlinear Greek English New Testament or Acts 7:19 "kata-sophian, "Pharao”, i.e. and "deceived them Pharaoh, i.e. Pharaoh deceived them (Sophian: compare that to Colossians 2:8, 4-23) or Acts 5:1-2 "Eno-sophisat" (i.e. and he kept back or misappropriated some of the money or proceeds).

2) That the Hebrew "Phalasaphaq" (Phoenician Baalsophat or Phalasaqer" i.e. falsehood, Hosea 7:1) entered Arabic as "falsafa", then English "falsify", thus philosophia as a cleverly invented venture is an education fallacial deceit and misnomer (Hebrew "Phalasu", i.e. workers of evil or idolatry: 2 Chronicles 15:16 "Repulsive" is Hebrew "Phalisiphar" Job 34: 32 or NIV or Brown, Driver \& Briggs, 2007: pp. 811-814. See Job 34:32 below.

Note: See Job 34:32 "Phalisipha" (Do evil no more. Also Isaiah 41:24 "Philasaphar" worthlessly man-made; see Daniel 4:9 and 18 "Aphialsaphir”, i.e. chief magician or Persian chief priests (Hebrew Old Testament, 2005). 


\section{Major Objective of This Study}

1) Just like the original Hebrew, Aramaic and Greek (also Latin), languages of the Holy Bible are available today for study, the original ancient Greek language texts (or writings) of classical ancient Greek philosophers, must also be made available for deeper studies, for the following reasons;

a) To ascertain their similarities to current translations.

b) And to find their original teachings compared to translations.

c) Failure to produce these documents constitutes the starting point to actually conclude that ancient philosophers were mere personifications, hence they did not exit.

2) That reliable neutral historical records must be produced by philosophers to prove the historicity of their godfathers (i.e. ancient Greek philosophers).

\section{Methodology}

1) Classical Aramaic, Hebrew, Arabic, Assyrian, Phoenician, Greek and Latin texts have been consulted.

2) From Arabic (Quranic) documents we glean succinctly (clearly) that the Hebrew "Phalasaphim" (Hosea 7:1 Phoenician "Phalasaqar") gave us the Arabic "falsafa", to the English "falsify”. (Ali, 1970).

3) That the Greek "Philos" (love) is from the Phoenician "Baala" (goddess or wife) to "Beula" (Philia) Isaiah 62:4, originally sexual immorality (Ahaba is Hebrew for love) which entered Hebrew as "Phallu" (Genesis 46:9 KJV), i.e. male "genitalia", traced to Genesis 35:22, when Reuben slept with his father's concubine "Bilha", hence one of his sons was called "Phallu" (in KJV) NIV is Pallu, see Chambers 1996; Phalic is penis which entered Greek as "Philos" (Human love). Divine love is "Agape".

Note: Concubine in Hebrew is "Phileges" (Hebrew Old Testament, 2005, BDB, 2007, pp 811-813). Also Zondervan, 1990, pp 1464-1480 "Phalasu”, Palasti, or Phileset (i.e. Philisti; 2 Chronicles 15:16) i.e. sexual immorality, uncircumcised, magic, Isaiah 2:6 or repulsive (Phalisipha) idolatry (i.e. Naphili, hypocrite compare this to Colossians 2:4-8, 8-23) etc.

\section{What is Education Personification Theory (or Fallacy)?}

Simply put, to personify names (i.e. transform cooked up names into human beings, or as if they existed as real human beings), then constitute it as a curriculum currently being taught in schools as Gospel truth is an education misnomer. That is, no education system (anywhere) should tolerate cooked up or cleverly invented myths and stories (which never happened) to be taught in our schools; Harry Boer (1980) in a Short History of the Early Church, cited by Father Tertullian (200BC) who was so annoyed with Greek ophites and related academics of wisdom. He said that he thought those academics taught the useful things, only for him to enter and discover that in what they called "Books of Wisdom" were contained fairy tales of the "Phoebus" (Phili, i.e. rival and opposition gods from the Phoenician "Baalis" (Phalis, i.e. to be against or man-made), being rival gods often fighting senselessly, including Jupiter raping his own sister (Hebrew "Sapheca") see Isaiah 2:6 "Philisti are Sophiku (i.e. sexually immoral pagans following many (soephim) gods (sephir) Boer, 1980: p. 50, Hebrew Old Testament, 2005, 1 Kings 18:21.

\section{The Sophis Concept in the Education Personification Theory}

Please check 2 Peter 1:16 in Brown and Comfort (1990) Interlinear Greek-English New Testament which used the word "Sophis" translated "cleverly invented" as Apostle Peter cleverly struggled to pull the developing Church away from possibly developing myths and legends around Christ, thus could have led to a personification theory round Jesus and possibly that Jesus did not exist. Hence, when Peter wrote that Jesus was not a "Sophis" or "Sesophismenos" he clearly dispelled and filled a future personification theory that after all it was possible Jesus was only a personification or a cleverly invented story, which this study accuses ancient Greek philosophers of.

Research Statistics: Please note the following collated data on a related research study.

\section{Statistical Method}

Used Nnaji (2012, 2013a) $\pm 3 / 4, \pm 1 / 2$ Stachistics Formulae of the Bio-Identical Estimations Calculations (Table 1). 
Table 1. Nigerian $\pm 3 / 4 \pm 1 / 4$ Stachistics estimation formulae (Nnaji in Idisi, 2013b: IJMPD, Vol. 3 No. 1).

\begin{tabular}{|c|c|c|c|c|c|c|c|}
\hline & Date & B.A Philosophy & $\begin{array}{l}\text { LLB Law and } \\
\text { Sociology }\end{array}$ & $\begin{array}{l}\text { BSc Chemistry } \\
\text { and Physics }\end{array}$ & $\begin{array}{l}\text { MBBS } \\
\text { Medicine }\end{array}$ & $\begin{array}{c}\text { B.A } \\
\text { Religion }\end{array}$ & $\begin{array}{c}\text { B.Ed } \\
\text { Education }\end{array}$ \\
\hline 1. & $\begin{array}{l}1980 \\
\text { Enugu (Old Anambra), } \\
\text { Imo, Benue, Sokoto }\end{array}$ & $\begin{array}{l} \pm 11 \% \text { year } \\
\text { ended graduates }\end{array}$ & $\begin{array}{l} \pm 13 \% \text { year ended } \\
\text { university graduates. }\end{array}$ & $\pm 30 \%$ graduates & $\pm 15 \%$ graduates & $\begin{array}{l} \pm 6 \% \\
\text { graduates }\end{array}$ & $\pm 20 \%$ graduates \\
\hline \multicolumn{8}{|c|}{ Summary Sheet: \pm immorality questions (see NPE, 2004) } \\
\hline 2. & $\begin{array}{l}\mathbf{2 0 0 0} \\
\text { Lagos, Ogun, Edo, } \\
\text { Abuja }\end{array}$ & $\pm 9 \%$ graduates & $\pm 18 \%$ graduates & $\pm 18 \%$ graduates & $\pm 15 \%$ graduates & $\begin{array}{l} \pm 7 \% \\
\text { graduates }\end{array}$ & $\begin{array}{l} \pm 15 \% \\
\text { graduates. }\end{array}$ \\
\hline \multicolumn{8}{|c|}{ Summary Sheet: \pm criminal morality } \\
\hline 3. & $\begin{array}{l}\mathbf{2 0 1 0} \\
\text { Kano, Bauchi, Jigawa, } \\
\text { Borno, Niger, Kaduna, } \\
\text { Rivers, Akwa Ibom }\end{array}$ & $\pm 10 \%$ & $\pm 30 \%$ graduates & $\pm 13 \%$ graduates & $\pm 10 \%$ graduates & $\begin{array}{l} \pm 9 \% \\
\text { graduates }\end{array}$ & $\pm 10 \%$ graduates \\
\hline & Iry Sheet: \pm criminal ext & remism; ibid. Ref & 2014 & & & & \\
\hline
\end{tabular}

Data Theology, 2013 Field Questionnaire Estimations (Journal of Information and Statistics Theology (Enugu: Theometry).

\section{Definition of Terms and Literature Analysis}

\subsection{Education-Personification Theory}

This means teaching personified characters as if they are real human beings, which imply that what is not historically true is being presented as truth. Chambers (1996 pp 417-419) Latin "Educare" is to bring up, from the Greek "Paedo" (i.e. aedo) or Paediatrics, i.e. child medicine or Paedagogue, i.e. to lead a child, to teach and train (Didactos, or Didaskalos, i.e. teacher). Didactors is the teaching skill, or how to acquire teaching methods and skills (Bromiley, 1985: p. 753). Hawkins (1995) defined personification as though, thought to be of the French "personnifier", i.e. personal or belonging to self, or oneself (ibid p 1033) the word goes back to the Phoenician "Basar" (i.e. Hebrew "Paser or Palas" or flesh or the human being; BDB, 2007, p. 142, 814). Technically, "personify" means to treat an abstract or a non-living object as if it were a human being; i.e. you take a name and address it as if it is human, while also attributing words to that name or object as if the name or object actually spoke those words (Chambers, 1996, p1033). Bromiley, 1985; Brown and Comfort (1990) trace the word "Theory" to the New Testament Greek "Theso" (I (Jesus) laid down (Theso) my life) from Theos (God) to Thewreo (Theoreo) (Hebrew "Ora”) i.e. to look -religiously (Blepo is to see) while to view and see is "eideon" (i.e. videon). Thus, the use of Theoreo in the Greek New Testament often has a strong religious connotation (Brown \& Comfort, 1990). Note: Theatron (i.e. Theatre) which means watched by the gods or God; or a worshipper of God “Thuatira” (Acts 16:14) Bromiley, 1985, pp: 318, 706.

\subsection{Historicity}

The Greek New Testament word "Istoreo" means to visit and see for yourself (Aland \& Newman, 1983: p. 88). They cited Apostle Paul use of that word about visiting his mission fields. Episkope (Bishop, also means visiting, i.e. of the overseer). Hence, history merely should not be telling or recording events (and stories) of the past (Archaia), however, what is the authenticity, i.e. reality of those events, see (2 Peter 1:16): See F. Buchsel in Bromiley, 1985: pp. 377-378; Galatians 1: 1-18, Apostle Paul "Istoreosan” (Historeo) i.e. visited Cephas (Peter) to know Peter more. Brown and Comfort, 1990, Interlinear Greek-English New Testament. See 2 Peter 1:16.

"For we have not told you cleverly invented (Greek 'Sophis') stories (Muthos or myth) but we saw and him (eyewitnesses)."

\subsection{Ancient (i.e. The Classics, or Best of The Past)}

1) The Greek “Archaios” (Old) or Hebrew "Pala”, Palasu or Phalasu, i.e. Philisti or Palasti, i.e. Palestine which means outdated or idolatry, i.e. consulting spirits and gods (BDB, 2007, pp. 811-814, 84) Baali, to Phaali, i.e. inquiry through ancient or outdated means, i.e. occultic evil spirits and powers. The Greek "Archaus" (Old) 
is related to "Archo" (i.e. beginners of ancient systems of government like monarchy, i.e. kingship) Metzger, 2001, Bromiley, 1985: p. 81.

2) Classics from the Latin "Classicus or classis" refers to mustering or gathering the best of the past especially ancient Graeco-Roman (and Hebrew and Aramaic) culture and civilizations, including their customs, laws, religions, education, financial systems, philosophy etc. Wilson, 1965: p. 22, Chambers 1996.

\subsection{Greek (and Ancient Greek Philosophy)}

The Anglo-Saxon "Graecius" gave us the word "Greek" from the "Aegeos”, i.e. the ancient "Attica” people living in the present geographical zone called "Greece" in the European East close to Turkey (Chambers, 1996; New \& Philips, 1953). The original name of the Greeks was "Ellenes" from their presumed forefather "or Hero" "Hellas" which gave us "Hellenism", i.e. pagan Greek culture and civilization (including their philosophies) described by the Jews as "pagan" see Isaiah 2:6, "Philosophiqu" i.e. idolatry that mocks God, see Acts 17:22-32 Athens (named after the goddess Athena) was a pagan city filled with manmade gods: see Isaiah 41:24 Hebrew "Phalisaphir" (consulting man-made gods like the oracle of Delphi; Hebrew "Philosophia", i.e. spoken (phe) by the Devil or serpent (sophis; Greek "Pytho") i.e. fortune telling through the familiar spirit of the "puthon". Acts 16:16, Phoenician "Balzeboul", 2 Kings 1:1-7; or Baalzephon; Exous 14:1, or Baalsophot (Hebrew "Philasophia”) i.e. leaders of occultic schools falsely called schools or academies of wisdom, see 1 Timothy 6:20), see also Ecclesiastes 12:11 "Baal or Phalasophot" wrongly translated as "masters of assemblies", but properly translated in Isaiah 50:8 and Nahum 3:4 as "the Accuser or opposer", or witchcraft (Phoenician "Baalcosophim", Hebrew "Phalasapha” Arabic "falsafa”, English “falsify", Hosea 7:1, "liars”, Aramaic "Phalasaqer”, Hebrew "Phalasaphaq”) Hebrew Old Testament, 2005, SDHT, London, 1940 etc.

Please Note: The Greek goddess of wisdom "Pallas Athene" is "Phalasaphya" in Hebrew (i.e. the crafty virgin goddess).

\subsection{Philosophy}

1) The traditional definition of the word "Philosophy" is "love" (philos) for wisdom from Chaldean or Cosodin, cashdim, casdom, the wisdom, i.e. Daniel 2:2, etc. magicians, astrologers and sorcerers from Babylon, (i.e. Chaldea).

Note: Hebrew "cesephi" or Gesem gave us sorcery, which gave us "Socrates or Socratim" i.e. magic or occultic" (BDB, 2007, pp506, 355 etc.) being the reason why Socrates was executed in 399BC by the Athenian government for being a member of the cult or oracle of Delphi at Parnassus outside Athens, being a rival cult to that of the Athenian Zeus at Olympus (New and Philips, pp. 94-95; Wilson, 1965; Asaju, 1999: p. 36).

Note: Pythagoras was a member of the cult of Dionysius (Acts 17:29-31), Pythagoras was a fortune teller; Acts 16:16. Heraclitus was at the level of a pagan priest (i.e. Hebrew sophiku).

2) The traditional definition of philosophy, i.e. love for wisdom has been discovered to be entirely false, i.e. cleverly invented. (Greek "sesophismenos", 2 Peter 1:16).

3) The Truth:

a) Love for wisdom did not give us the word "Philosophy", i.e. love (philos) is from Hebrew "Phallu-Sopheca (the penis) BDB 2007, p 1046, 1056, a fertility symbol of the Husband or Lord "Baal” (Phaal, i.e. evil) god of the Philistines and Phoenicians (2 Kings 1:1-3), see Genesis35:22 Reuben committed adultery with his father's concubine, i.e. "Bilha" (Phileges is concubine in Hebrew). Hence he called one of his sons "Phalu”, KJV, or Pallu, NIV; Genesis 46:9.

b) Note: "Baala" (Pallas) was the wife or sexual partner (Philia) of Baal the husband or Lord (Eluphi) BDB, 2007, pp 127-128, Hebrew Old Testament, 2005, 2 Kings 1:1-3, 2 Kings 23:1-14, 1 Kings 11:1-end (Solomon turns to the Baals through his concubines "Philegsim" who also worshipped "Asteroth Ashraphe).

c) Very Important:

i. The word philosophy did not come from its definition, but from how you seek that wisdom which was through "Baali", or Phaali, i.e. inspired or enquired from "Baali or Phaali" (2 Kings 1:1-3) i.e. from the occult (Sophaot) i.e. hidden knowledge etc.

ii. See KJV Ezekiel 13:18-20 "Pillows or Philos", i.e. magic in NIV; while Hebrew "Sophaot is cultic, hidden, veil, secret or kerchief, (Ezekiel 13:18-20.

iii. In 1 Kings 18:21 “Hebrew "Baala” "Soephim” is following many gods, many ways or many opinions. 
iv. In the Hebrew Old Testament it is "Phensopha" (2 Kings 10:23, i.e. worshippers of Baal) in 1 Kings 18:21, its Baalsoephim (Phalasophim) also written as "Phe-sophim” i.e. following or consulting many gods (or polytheism) or syncretism.

d) i. Being the reason why in 527/529CE Emperor Justinian of the Roman Empire (Byzantine) banned philosophy and their academies (as Hellene or pagan or idolatry) because true to Colossians 2:8 (4-23) philosophia as applied by Apostle Paul means leading away or misleading (Asopha) Christians; or adding (Losopha) falsehood (Phalasaqer: Hosea 7:1) to the Christian message (Brockman and Pescantini; 2004, Philosophy NET 2015).

i. Note: when it is stated that ancient Greek philosophers went to Egypt to learn philosophy, see Exodus 7:11 "Vilasaphim" (Philasaphim, i.e. magic or consulting the dead (Isaiah 8:19) also (1 Samuel 28:1-7) that was what they learnt. (Hebrew Old Testament, 2005).

e) A research finding: The banning of philosophy by Justinian in c529CE was effectively the end of pagan, classical or ancient Greek philosophy (i.e. consulting the occult for wisdom or knowledge; (i.e. paganism: Hebrew "sophiku”, Isaiah 2;6= Philisti-Sophiku= pagans or fortune tellers see Tertullian, (120CE) in Boer, 1980: p. 50, i.e. repulsive (Hebrew Phalisipha: Isaiah 41:24, Job 34:32) manmade gods or shrine prostitution (2 Chronicles 15:16) Miphilasu.

f) For c700 years, philosophy died in Europe until c12200 from the times of Thomas Aquinas (1225-1274) when Catholic Reverend Fathers revived philosophy (with Islamic help) in their arguments for the existence of God (New \& Philips, 1953: p. 249).

g) Another Truth: New and Philips (1953, pp. 247-249) when Constantinople fell to the Muslims, the Byzantine classical Greek culture and civilization collections (including philosophy writings) entered Muslim hands. From 1085CE Christian scholars (scholastics or Reverend Fathers) went to Spain to collect the Greek philosophy writings, which they did not get, but retranslated Plato, Aristotle etc. from Arabic, not from the original Greek.

\section{Limitations of the Study}

1) Non availability of original ancient Greek language texts of ancient Greek philosophers hinders proper search into the true human existence of those philosophers.

2) Added to the truth and facts that 99\% translated works of ancient Greek philosophy have been highly embellished with salt and pepper to give them better tastes; hence their truths or original messages are highly falsified.

\section{Research Conclusions and Findings}

1) Only the original ancient Greek language documents or writings of ancient (classical) Greek philosophers can give one a measure of conviction that they actually existed as truly physical historical figures.

2) That c,1850 BC the word "Vilasaphim" or "Phalisaphim" (i.e. magicians was used in Exodus 7:11) while Job 34:32 (Before 1,000BC) was Phalisiphat (i.e. evil). See also Isaiah 41:24 "Phalisaphar” (manmade gods). Also Hosea 7:1 "Phalasaqer” (falsehood) or Philisophiku (to mock God or paganism, Isaiah 2:6) etc.

3) That 2 Peter 1:16, Acts 7:19, Genesis 11:7-9, Acts 5:1-2, Mathew 10:16, 2 Kings 10:23 (Phensopha: Baal devotees), Job 34:32, Exodus 7:11, Daniel 2:2, Colossians 2:4-8, Daniel 4:9 and 18 (Aphialsaphir: magician), Isaiah 8:19, (Saphilsaphim: consulting witchcraft and the dead) Isaiah 2:6, Hosea 7:1, Ezekiel 13:18-20, Ecclesiastes 12:11, Isaiah 50:8, Nahum 3:4 and 1 Samuel 28:1-11, “Baalas-ot”, or Phalasoph: i.e. necromancy etc. were all occultic indications of inquiry. If the Hebrew and Aramaic Old Testament are opened up to these Bible passages, one word looms up on each passage, that word is "Phalisipha" (Job 34:32 evil deeds) in Hosea 7:1, it is "Phalasaqer" (to tell lies or falsehood) while Phalasaqad is the liar. It entered Arabic as "falsafa” then to English as "falsify" (Hebrew Old Testament 2005); in Daniel 4:9, it is explicitly “Aphilasaphir” (translated as "chief magician”, originally Aramaic, “chief priest or spiritual leader; in Chaldea it is Beltesazzar, Baalzeboul or Baalsephon (Exodus 14:1), to Phoenician (Aramaic "Phalasephon” (2 Kings 1:1-3) i.e. find out or inquire from the gods or the occult (Asaphim BDB, 2007, p 355, 365, 121-127, 506 etc.).

4) Very Important

a) That the word "philosophy” has its true meanings in 2 Peter 1:16 “cleverly invented” (Greek "Sophis”, He- 
brew "Sophen", in serpent. See Mathew 10:16, "be (ophis) "crafty" as serpents (sophen)(Hebrew "Yapheli, Greek "Ophis”). See Acts 7:19 "Kata-Sophian" (and Pharaoh deceived them). Compare to Colossians 2:8 "Philosophia” i.e. to lead astray, mislead or captured into falsehood (Hebrew Asopha) by false and human (Phaal: James 3:13-17; v16-human wisdom) or occultic teachings or reasoning (Hebrew "Sopherim" Nehemiah 7:57 (i.e. trained by Solomon) or "Soephu", 1 Kings 18:21),

b) see also 2 Kings 10:23, Hebrew "Phensopha”, i.e. none worshippers of God, which corresponds to Isaiah 2:6, "Philosophiku", i.e. those who mock or oppose God with idolatry or paganism, i.e. many gods or man-made opinions (Phalasu or Palasu) with manmade gods (Phalisaphar; Isaiah 41:24).

5) See New and Philips (1953) for Pallas Athene (Greek goddess of wisdom) i.e. Hebrew "Phalasaphya", (goddess of falsehood) or beautiful and sound, but false (Colossians 2:4).

a) That in all the above and more, we currently have in our schools curriculum worldwide, a cleverly invented "sophis" (2 Peter 1:16) field of study called Philosophia, which continually craftily deceives (Acts 7:19 and Mathew 10:16) students and enthusiasts that it teaches wisdom.

b) Note: "Be ye as crafty (Hebrew Nabin-Naphili) as a serpent (Hebrew "Sophe" Nahas or Nahasuphia; 2 Kings 18:4).

c) Particularly that philosophy currently is not a natural field of study, but craftily packaged or invented to deceive gullible students.

6) Please Note:

a) That if philosophy really develops human intelligence, what is Greece today in the index or report card of world powers today.

b) Also, if philosophy truly is love for wisdom, how come the Holy Bible totally condemned it (Colossians 2:8 and 23, 1 Corinthians 1:26, James 3:13-17 etc.)

c) Also how come philosophy was banned in 170BC and 529CE?

7) That experts and managers of our educational systems should take another look at this thing called philosophy to find out.

a) Its true origins.

b) Its true meanings.

c) The historicity of its ancient characters and their messages.

d) Was Socrates truly a sorcerer, including Pythagoras (a chief priest) of the Dionysian cult and a fortune teller (currently called philosophy) i.e. through the serpent spirit (Greek Pytho) Hebrew "Sophis" or familiar spirit of divination, i.e. inquiry through the occoultos (Hebrew "Asaphim or Mecasaphim”, i.e. sorcery which gave us Socrates, BDB, 2007: p. 355, 506; Mansoor, 2010: pp. 239-247; Hebrew Old Testament, 2005).

\section{Research Suggestions and Observations}

1) That the true relevance or importance of philosophy and the social problems it is solving should be identified and confirmed.

2) Particularly that from undocumented data shows that true philosophers (not moderates) have no respect for God, religion and morality; and that those of them who claim religious, are actually what Hebrew calls "Naphuli, Hanaphi” or Phalasu (i.e. hypocrisy).

3) Please see if you can read the Old Testament Hebrew, if not find someone who can and confirm the above citations.

4) Can our education chiefs investigate and find out why philosophy was banned in history over four times from before and after Christ (egs 170BC and 529CE) by who; why and where; then who revived philosophy again, after c700 years? Why? etc.

i. Particularly, what was the real reason why Athens executed Socrates in 399BC (i.e. what do philosophers mean by "he was corrupting the youths of Athens?)

ii. Also, again if philosophy truly is love for wisdom, how come Colossians 2:8 totally condemned it, just as Justinian banned it etc.?

\section{References}

Aland, K. \& Newman, B. (1983). The Greek New Testament and Lexicon. Stuttgart: UBS. 3rd Edition Corrected.

Ali, Y. (1970). The Holy Quran. Pakistan: Curzon. 
Asaju, D. F. (1999). Christian Foundations (p. 36). Ilorin: Bahfik.

Boer, H. (1980). History of the Early Church. Grand Rapids: Eerdsman.

Bromiley, G. (1985). The Theological Dictionary of the New Testament. Grand Rapids: Eerdsman.

Brown, R., \& Comfort, P. (1990). Interlinear Greek-English New Testament. Illinois: Tyndale.

Brown, R., Driver, S. C., \& Briggs, C. (2007). Biblical Hebrew Lexicon. Hendrickson, 431-435.

Maer, P. (1988). Josephus Essentials. Grand Rapids: Kregel.

Mansoor, M. (2010). Biblical Hebrew Step by Step (pp. 232, 243, 247). 2nd Edition, Grand Rapids: Baker.

Metzger, B. (2001). The Greek New Testament Lexicon (pp. 49, 63-64,73, 105). Illinois: Baker.

New, C., \& Philips, C. (1953). World History from Ancient Times to 1776. Toronto and London: Dent and Clarke. Philosophy NET, 2015.

Nnaji, C. O. (2013a). Data Theology. Journal of Information and Statistics Theology. Enugu: Theometry.

Nnaji, C. O. (2013b). Introduction to Stachistics Estimation Formular. Abuja International Journal of Modern Perspectives and Development, 3, 38-49.

NPE, National Policy on Education (2004).

Wilson, A. (1965). The EUP Concise Latin and English Dictionary (p. 76). London: The English Universities Press. 